\title{
The Call for a Secular Government in Muslim Malaysia: The Rise of a Social Movement of Intelligentsia Critiquing an Islamic Malaysia and Fighting for Equal Rights for all Citizens
}

\author{
Benjamin Pwee \\ \{benpwee68@gmail.com\} \\ Faculty of Political Science, International Islamic University of Malaysia, Malaysia
}

\begin{abstract}
Over the past few decades, there has been growing calls by various sectors of Malaysia's minorities, for equal rights and treatment by the Malaysia Government as citizens under Malaysia's Federal Constitution. These groups range from gender-based, to race-based, to religion-based. They share the same concerns about the Government and Shariah Courts extending the application and reach of Islamic laws to non-Muslims, and the unfair and unequal treatment of non-Muslims based on Islamic law and not on Constitutional law. Many of these take the form of social movements, and are social because they are defined by a shared community identity based on gender, race or religion. However, there is an increasingly visible social movement of intelligentsia that share a common appeal to Constitutional law, and not to a shared gender, race or religious identity. These include academics Dr Kam-Weng Ng, Dr Helen Ting, and Dr Maszlee Malik, and Attorney-General Tommy Thomas.
\end{abstract}

Keywords: Malaysia, politics, intelligentsia, Islam, Shariah, Constitutional, law.

\section{Introduction}

Over the past recent years, there has been more than ten major and minor terrorist attacks in Southeast Asia associated with extremist militant Islam. And these have occured across the Southeast Asian peninsula, from Indonesia to Singapore to Malaysia to Thailand to the Philippines. These include two suicide bombers in a bus station in Indonesia, bomb blasts outside a shopping mall in Thailand, ISIS fighting in South Philippines [1] a foiled ISIS attempt to fire a rocket to Singapore [2], and a grenade attack in a nightclub in Malaysia [3].

Various other religious-related controversies were also being played out in Islamic Malaysia, where local Muslims were in outcry against local Christians using the word "Allah" to refer to the Christian God. The courts sided the Muslims and outlawed the Christians from using the word "Allah". The Christian community takes a historical approach and argued that the word "Allah" pre-dates Islam, whilst the government and the courts argue that it is a matter of national security and public order, as the word could confuse Muslims and turn them away from Islam [4]. Another well-known landmark court case in Malaysia was the failed legal attempt by Lina Joy, a Malay convert from Islam to Christianity, to not have her religion assigned as "Islam" on her identity card, which sparked a public debate about apostasy in Malaysia [5]. 
Whilst these events seem to be more related to religion, it triggered a series of ongoing debate amongst non-Muslims and non-Malays in Malaysia with the Malaysian government authorities, on the rights and freedoms of non-Muslims and non-Malays in the area of religion, religious beliefs and religious practices. This was further exacerbated by the Malaysian government and ruling political party UMNO, playing the Islamic religious card in local elections, as well as various provincial and local level religious leaders calling for the same application of Islamic Shar'ia and hudud laws to all Malaysian citizens, regardless of their race or religion. This led to public outcries from the non-Muslim and non-Malay communities in Malaysia, appealing to Malaysia's Federal Constitution that protected the rights and freedom of religious belief of all citizens.

Two local Protestant Christian civic thinkers and leaders of ethnic Chinese Malaysian descent, have written prolifically on this matter - Dr Ng Kam Weng (a Cambridge-educated local Christian theologian) and Mr Eugene Yapp (a local Christian constitutional lawyer). Both took a clearly-institutional angle to the debate, and argued from Malaysia's Federal Constitution against the increasing Islamization of Malaysia, and the application of Islamic law for all Malaysian citizens regardless of race or religion. This became especially pronounced with the calls of local Islamic political party PAS, and other local religious leaders, for the revival of Islamic hudud laws, and applying them on all and sundry in Malaysia.

Others like Malaysian Chinese academic Helen Ting [6], and Malaysian Indian and current Attorney-General Tommy Thomas [7], have also written extensively on the question of Malaysian identity based on the Constitution, and irregardless of race and religion, calling for a "secular Malaysia", and a fair and just treatment and recognition of non-Malay Malaysians as equal in citizen rights before the State, and before the Law. What is even more interesting, is the recent writings of a British-educated Malay-Muslim Malaysian political science academic from International Islamic University of Malaysia named Maszlee Malik, who has published a few key works on promoting "good governance" and "common space" based on Islam and the Qu'ran, where all citizens in Malaysia are equal, regardless of race or religion [8]. Maszlee Malik went on to become Education Minister.

This paper attempts to identify and articulate this emerging social movement of academics, lawyers and other intelligentsia in Malaysia, that is questioning the race- and religion-based politics of national identity, and taking a constitutional approach to push for a secular government that recognises and treats every citizen equally and fairly, regardless of race or religion. This paper attempts to dissect and analyse the various strands and factors tied-up in this ongoing debate, and looks specifically at how non-foundational relativistic discourse theory falls apart in being able to interpret or offer posible solutions and ways forward, when faced with a foundational and theistic religion like Islam in Malaysia, that stakes its claim on the centrality of Allah (God) in public theology, state and government.

\section{Apparent Problem}

This paper posits the apparent problem, as a fundamentally essentialist and monotheistic Islamic public theology, being the professed official "state religion" of a pluralist, multireligious, multi-cultural and non-Islamic state that is modern democratic Malaysia, and whether such an Islamic public theology can allow for the peaceful (and equal?) co-existence 
of non-Muslim and non-Malay ethnic minority groups under a British-modelled Federal Constitution that protects freedom of religious belief and practice for all.

For if a fundamentally essentialist and monotheistic Islamic public theology as official "state religion" has no room for, nor any tolerance for, non-Muslim and non-Malay Malaysian citizens amongst its midst, and is unable to recognise and protect them as equal citizens under Federal law, then Malaysia will continue to be fraught with such ongoing "religious" controversies and debates, and social movements that fight against this will continue to surface and grow.

What is interesting about Malaysia as a case study that is different from the usual studies and literature on Islam and politics, is that it is a modern secular democratic nation-state that professes Islam as its state religion, but does not claim to be an Islamic State, and that its brand of Islam is that of Southeast Asia, tied-up with local ethnic Malay cultural identity, and different and not derived from Arabic Islam from the Middle East. This means that the two extreme bodies of traditional Islamic studies and literature do not apply to Malaysia - on the one hand, Muslims as minority groups in non-Muslim countries/states (like the UK, USA, China, Thailand, India, Japan); on the other hand, Muslims as majority group in self-declared and primarily Arabic Islamic countries/states like Saudi and the other GCC countries.

We need to find a way forward in terms of political science, theory and theology in Malaysia for a majority-Islamic political theology nation like Malaysia to embrace and protect non-Muslim citizens as equals with the right to freedom of religious belief and practice, so it could potentially become a model or reference point for other similar non-Arabic majorityMuslim countries like Indonesia, Brunei, Pakistan, and Central Asia.

This upcoming social movement calling for a secular Malaysia, advocates a different basis for political and national identity - one based on the concept of shared political space built on common good, and not one based on shared common religion or ethnicity or origin. The proposed end, is to appeal to concepts of common good and natural theology, to accept the revivial of foundational, essentialist, theistic political theology back into the public square of politics and government, whilst embracing the co-existence of pluralism, diversity and discourse in its midst.

\section{Methodology}

This paper uses an archival history, library and documents search methodology. It draws from selected published writings on related themes, especially by local Malaysian authors, researchers and academics. It takes a critical analysis approach to analyse, compare and contrast what different actors are saying about common topics like Islam in Malaysia, citizenship rights, and other related themes. It also draws on key concepts of constitutional law, religious political thought, secular and Islamic states and government, and examines these concepts within the context of Malaysia.

\section{Key Themes}

There are several key themes that this paper draws from and refers to: 


\subsection{A Constitutional/Institutional Approach}

Academics and lawyers the likes of $\mathrm{Ng}$ Kam Weng and Eugene Yapp are taking a constitutional/institutional legal approach, appealing to the current Malaysia Federal Constitution as a basis for argument and debate against pro-Islamic Law proponents, and advocating governance based on secular Constitutional Law.

It is worth pointing out that the Prophet Muhammad himself crafted and wrote the Islamic Consitution of Medina, to govern the first Muslim polity he founded in Medina, and that the first four Rightly-Guided Caliphs themselves had similarly used written and codified laws to govern the first four Caliphates under each of their charge. This not only shows that there is a basis for Islamic constitutional and institutional approaches fully consistent with Islam, but also that much further work can and should be done in this area of Islamic constitutional and institutional law, that can be different from its Western counterpart, but need not conflict, and can find shared common ground.

Harvard Law School Professor Noah Feldman has written insightfully about what he calls "Islamic constitutional state", which he believes is the way forward for majority-Muslim Islamic states in today's multi-religious, multi-racial, multi-ethnic society and citizenry [9].

\section{2 "Secular" versus "Saecular"}

"Post-modernism" as defined in Western liberal democracy, is not a helpful term to use for politics in Asia, where the trajectory of philosopy and political science in Asia has not gone through the modernist and post-modernist "God is Dead" discourse. The concept of "God" is very much alive in Asia, especially in politics, whether it be Muslim Malaysia, or Buddhist Thailand, or Hindu India, or Catholic Philippines. And for this reason, the term "secular" as used in Western liberalism is also not a helpful term to use for politics in Asia, as "secular" in the West typically means non-religious, the non-existence of God/gods, and the relegation of religion and religious belief to the private and the personal.

A more helpful term used by Christian theologians like Miroslav Volf as well as Islamic thinkers like Muhammad Asad, is "saecular", ie everything created by God in the material and immaterial realm, from the word "saeculum" (ie world). Using the term "saecular" in political theory in Asia where religion is very much at the forefront in the public and political square, is a lot more relevant and helpful, as it recognises the place of both religious and non-religions theories, theologies and thinking in politics and government.

\subsection{Breakdown of the Modern Secular Nation State}

There is a groundswell and myriad of academics and theorists working in the areas of transationationalism, international relations, globalisation, regionalisation and cross-border alliances and identities in the past decade, that increasingly show the arbitrariness of the concept of the modern secular nation state built on the historical Western Westphalia concept of a "nation state". Such a Western concept of "nation state" is fast breaking down, as nationstates face all kinds of cross-border and transnational challenges, and begin to define themselves in transnational cross-border alliances like the GCC, Arab League of Nations, ASEAN, APEC, etc.

Such new trends also impact on the concept of citizenship and national identity built on the concept of the nation-state, and reveal how increasingly fluid citizenship and national identity has become, what with dual citizenship holders, China's recent offer to issue an 
"ethnic Chinese" identity card to all ethnic Chinese globally regardless of citizenship or nationality, and Muslims in Southeast Asia increasingly identifying themselves with Arabic Islamic identity of the Middle East, the GCC and the Arabic League of Nations. These new trends invariably therefore also impact on the concept of Malaysia as a nation-state, and Malaysia as a citizenship and political identity.

There is also an increasingly explored concept of "Zomia", coined by Van Schendel and developed by James Scott, to refer to the huge mass of mainland Southeast Asia (Indochina, Southwest China and the Mekong River basin lowlands), where local ethnic peoples live beyond the control and definition of nation-states and governments, many of whom are either state-less, or holding one citizenship but living and operating cross-border in the edges and nexus of two to three different Southeast Asian countries' borders. Such borderless communities of people lead the way for similar porous cross-border communities like Northern Islamic Malaysia and Southern Muslim Thailand, Northern Islamic Borneo (East Malaysia) and Southern Muslim Philippines, and Southern Malaysia and Singapore. The rise of mobile communities like the Rohingya Muslims in Southeast Asia, also begin to challenge the concept of "nation state".

\subsection{Revival/return of God and Religion Into Politics and the Public Square}

The rise of Islam in the politics in Malaysia also reflect the increasing revival and return of God and religion back into politics and the public square in politics in Asia. This will increasingly bring to the fore arguments about whether such a foundational, essential and theistic political theology can accept, embrace and protect the existence, rights and freedoms of citizens of other faiths and religions, as well as those who do not believe in any deity or religious faith, by appealing to basic concepts of natural theology, moral ethics, shared interests and common ground. This is exactly what Muslim writers like Maszlee Malik advocate.

\section{A Scan of the Research Landscape}

\subsection{Islamic Political Theology in Malaysia}

There is a lot written on Islam and politics in Malaysia over the past few decades, but mostly centred on Malaysia's partisan politics and national elections, and Islam in relation to the Malay race and cultural/ethnic identity. There is a dearth of published local Islamic political thinking and writing, even from within the local Islamic community and leaders. The closest that has come to this area is the writings of local Malaysian Muslim philospher Naquib al-Attas, who takes a Sufist approach to Islam in applying it to Malaysia, and more recently, local Malaysian academic and recent politician, Maszlee Malik, who takes a Western moralethical approach to Islam and good governance. Most of other local Islamic teachers have focused on more religious application of Islam to the personal and private lives of Muslims in Malaysia, like in family, marriage, food, etc, and what constitutes haram or non-haram acts in daily living.

Counters to Islamic political theology in Malaysia have come in two key areas: firstly, from the writings of Christian thinkers and lawyers like Ng Kam Weng and Eugene Yapp, who write from the Christian religious community fighting hard against Islamic law being 
applied to non-Muslims in Malaysia, and the apparent discrimination against non-Muslims as second-class citizens; and secondly, from the writings of academics and jurists like Helen Ting and Thomas Thomas, who write from the secular perspective of national and political identity being non-Islamic and a-religious, and the apparent discrimination against nonMalays as not being bumiputras (local ethnic Malay people "of-the-land"). Both these areas of literature have tended to appeal to constitutional and institutional arguments to negate the all-arching role of Islam in politics, and call for a secular nation-state and government. Neither have been able to properly address or resolve the reality that theistic Islamic political theology is a reality in Malaysia, and neither have been able to propose ways forward that the Islamic community and political leaders have been able to accept.

\subsection{Secular Modern Nation-State and National Identity}

Literature around the concept of the modern nation-state have typically stayed within the discourse of international relations, comparing nation-states with regionalisation and transnational alliances. But in such literature, they typically assume that citizens believe in the concept of a modern nation-state, and the natio-state itself is a player in cross-border international politics. However, writers like James C. Scott's development of the idea of "zomia" have challenged th viability of the nation-state, and used other terms and concepts to define a polity of people, in terms of people-groups, ethnic/linguistic families, cross-border tribes, and transnational identities. Francis Fukumaya recently came up with his book on identity, that shows how much recent and alive this area is, and still much debated, contested and discussed.

The idea of a "secular" nation-state also assumes that the Westphalian nation-state is areligious, where religion and religious belief is banished from the public arena into the realm of the personal and the private, where politics and government remains "secular" and devoid of religious identity, influence or involvement. However, much writings in recent decades in both the Christian (Protestant and Catholic) and Muslim circles have sought to re-emphases the theistic worldview of religion, and how religion is not just a matter of relative personal private beliefs, but have larger societal and national impact in terms of public and political theology. Christian writers like Lesslie Newbigin, Miroslav Volf, Stanley Hauerwas, as well as Muslim writers like Ghazali, Muhammad Asad and Maszlee Malik, have all called for the recognition of a foundational, essential and theistic universe where there is a supreme supranatural deity that created the world and holds humankind accountable to ordering and managing it along moral-ethical lines.

And in the area of national identity, the literature surrounding this topic in Malaysia have revolved around race, ethnicity, culture, language, history of origins, and post-colonial modern nation-state institutional frameworks. Any discussion about Islamic and religious identity related to national identity has been tightly intertwined with the themes of race, ethnicity and culture, with not much written on national identity in terms of religious beliefs or political theology. Local academics like Helen Ting have made early forays into discussing this topic but have in recent years started to go down the path of gender (women in particular) and education (related to language and culture), Others like Thomas Thomas have argued for a secular national identity from a constitutional framework, and Maszlee Malik has written about good governance and a shared moral-ethical framework, but stops short of the topic of national identity. 


\subsection{Discourse Theory and Natural Theology}

Much of discourse theory applied to Malaysia has led to different narratives about politics and identity in Malaysia, eschewing any discussion or admission of a foundational, essential and theistic political position, whether from an Islamic or Christian or any other religious perspective. This reflects the general literature in the West around post-modern discourse theory, that assumes a "God-is-dead" theory, and relegates reality to relativistic constructivist approaches where everything depends on subjective perspective and interpretation of players involved in each discourse and narrative. The likes of Kristeva and other post-structuralists basically object to any possibility of shared objective moral-ethical truths outside of an individual's own position, and come right smack up against the essentialist theistic political theology of Islamic political thinking.

However, more recent thinkers in Western Christian academia have started to try and revive essentialist theistic political theology through a re-examination and re-appeal to natural theology. A good example is the writings of British Christian theologian Lesslie Newbigin, who lived as a missionary pastor for many years in India, who appealed extensively to the natural theology of Polyani. Similarly, British Christian academic Nigel Biggar appeals to the Finnis-Grisez School's advocacy for Natural Law as the basis for ethics. Interestingly, Malaysian Muslim academic-turned-politician Maszlee Malik himself also appeals to the concept of common morality and ethics based on universal truths and reality of a theistic universe. There is a lot of potential for this area of study to continue, and to make its way into the realm of political science in Asia.

\subsection{Identity Politics and Marginalised Groups}

The writings on identity politics range far and wide, from gender to race to a myriad of other identity factors. Specifically in the area of religion and politics in relation to identity, writers like Schlesinger, O'Niell and Jones explore themes of political marginalisation due to difference and class. Others like Cressida and Calhoun define identity politics in terms of social theory. Within Malaysia, it is local Roman Catholic ethnic-Chinese Malaysian academic Helen Ting who writes most extensively and specifically on identity politics in Malaysia, in relation to race, religion and citizenship.

There is a wealth of literature on marginalised groups and their struggle with identity politics, led by Will Kymlicka and others. They argue that marginalised peoples are often overlooked and left out of the majority discourse and narrative defining identity, and ways need to be created to embrace them. Marginalised group theories applied to the Islamic world have typically been applied to Muslims as marginalised minoritiy groups, especially in the West, India and China. But little is written by way of marginalised group theories applied to non-Muslims in majority-Muslim countries like Malaysia.

\subsection{Islamic Political Thinking and Malaysia}

The literature on Islamic political thinking through the past decades have taken a more intra-religious perspective, trying to understand Islamic thinkers through the centuries, and explaning and making them relevant to Muslims and Islamic communities today. However, much is focused on Islamic jurisprudence and personal piety, and application in the realm of the private, eg marriage, family, dress-code, food, etc. Not much has been written by way of Islamic political thinking from within the Muslim community for itself. 
Academics like Bernard Lewis and Karen Armstrong write about Islam and politics more with a focus on Middle East politics, and explaining basic Islam to non-Muslim audiences. Whilst laudable in their efforts in creating greater understanding of and for the Muslim community, their works do not explore or construct new possibilities in terms of Islamic political thinking for today.

Another group of Islamic scholars like Muhammad Asad and Fazlur Rahman write in English for a Western non-Muslim audience, and attempt to frame Islam in western models and concepts of democracy, freedom, etc, finding areas of commonality and overlap between Islamic political philosophy and Western democratic concepts. Again, whilst helpful, they do not totally address the inherent difference and conflict between an essentialist, theistic political theology of Islam, and a non-essentialist, relativistic, anti-deity theory of a secular modern democracy.

When it comes to Malaysia, most of the writings have been comparing and contrasting Islam and politics in Malaysia, with Islam and politics in Indonesia, Singapore and Brunei, the other nearby Southeast Asian countries within a Malay-Muslim peninsular and sea with sizeable local Muslim communities. And more recent writings have focused heavily on militant and extremist Islam, and containing Islamic terror and violence. Not much recent literature has focused constructively on how Islamic political thinking in Malaysia (or anywhere else in Muslim Southeast Asia) can become a positive political force in creating a peaceful environment for Muslims and non-Muslims alike to co-exist, co-operate and collaborate in politics and government.

\section{Future Directions for Research}

This paper hopes to point to possible ways forward in research, to address the Islamic trend towards a return of essentialist, theistic political theology back into the public square of politics and government, and find ways how such a trend can accommodate and embrace minority others who are not of the same faith or theistic belief, in a political identity of community that can be shared by all, regardless of race, religion or ethnicity.

Such a way forward is critical in the light of rising anti-religion and anti-religious discrimination social movements that are beginning to rear their heads, with Malaysia being a specific case in point. And with increasing relgious-related political and civil violence and acts of terror happening around the world, especially in Asia, such a research topic area becomes even more pressing, for the sake of a stable and sustainable polity to hold together communities and peoples with increasingly disparate social, national and political identities.

can be used as a template for journal. This Word document can be used as a template for journal. This Word document can be used as a template for journal. This Word document can be used as a template for journal. This Word document can be used as a template for journal 


\section{References}

[1] http://www.npr.org/sections/parallels/2017/06/11/530949383/how-big-a-threat-is-extremism-insoutheast-asia

[2] http://www.straitstimes.com/singapore/singapore-under-highest-terror-threat-in-recent-years-8key-points-from-mhas-terror-report

[3] http://www.channelnewsasia.com/news/asiapacific/malaysia-arrests-6-islamic-state-suspects8813294

[4] http://edition.cnn.com/2014/06/24/world/asia/malaysia-allah-ban/index.html

[5] https://www.google.com/amp/s/mobile.reuters.com/article/amp/idUSSP20856820070530

[6] Ting, Helen.: Social Construction of a Nation - A Theoretical Exploration, in Nationalism and Ethnic Politics (2008); The Politics of National Identity in West Malaysia, in Japanese Journal of Southeast Asian Studies (2009); and Race and its Competing Paradigms, in Transforming Malaysia: Dominant and Competing Paradigms, (2014)

[7] Thomas, Tommy.: Abuse of Power: Selected Works on the Law and Constitution, and Anything But The Law: Essays on Politics and Economics. Both published in 2016 by Strategic Information and Research Development Centre, Malaysia

[8] Malik, Maszlee.: Good Governance, and Good Governance, Civil Society and Islam, both published in 2016 by IIUM Press, Malaysia, and Foundations of Islamic Governance: A Southeast Asian Perspective, published 2017 by Routledge.

[9] Feldman, Noah.: The Fall and Rise of the Islamic State, Princeton Press (2008) 